\title{
Genetics of primary macronodular adrenal hyperplasia
}

\author{
Maria Candida Barisson Villares Fragoso ${ }^{1,2}$, Guilherme Asmar Alencar', \\ Antonio Marcondes Lerario ${ }^{2}$, Isabelle Bourdeau ${ }^{3}$, Madson Queiroz Almeida ${ }^{1,2}$, \\ Berenice Bilharinho Mendonca' and André Lacroix ${ }^{3}$
}

${ }^{1}$ Unidade de Suprarrenal, Disciplina de Endocrinologia e Metabologia, Hospital das Clínicas, Faculdade de Medicina da Universidade de São Paulo, São Paulo, Brazil

${ }^{2}$ Instituto do Câncer de São Paulo ICESP, São Paulo, Brazil

${ }^{3}$ Département de Médecine, Centre Hospitalier de l'Université de Montréal, Montreal, Quebec, Canada
Correspondence should be addressed to M C B V Fragoso Email maria.villares@hc.fm.usp.br

\begin{abstract}
ACTH-independent macronodular adrenal hyperplasia is a rare cause of Cushing's syndrome (CS), accounting for $<2 \%$ of all endogenous CS cases; however it is more frequently identified incidentally with sub-clinical cortisol secretion. Recently, cortisol secretion has been shown to be regulated by ectopic corticotropin, which is in turn produced by clusters of steroidogenic cells of the hyperplastic adrenal nodules. Hence, the term 'ACTH-independent' is not entirely appropriate for this disorder. Accordingly, the disease is designated primary macronodular adrenal hyperplasia (PMAH) in this review article. The means by which cortisol production is regulated in PMAH despite the suppressed levels of ACTH of pituitary origin is exceedingly complex. Several molecular events have been proposed to explain the enhanced cortisol secretion, increased cell proliferation, and nodule formation in PMAH. Nonetheless, the precise sequence of events and the molecular mechanisms underlying this condition remain unclear. The purpose of this review is therefore to present new insights on the molecular and genetic profile of PMAH pathophysiology, and to discuss the implications for disease progression.
\end{abstract}

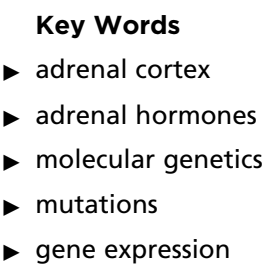

Journal of Endocrinology (2015) 224, R31-R43

\section{Introduction}

Adrenocorticotropic hormone (ACTH)-independent macronodular adrenal hyperplasia (AIMAH) is a rare and insidious cause of Cushing's syndrome (CS), and accounts for $<2 \%$ of all endogenous cases of CS (Arnaldi et al. 2003, Lacroix \& Bourdeau 2005, Newell-Price et al. 2006, Nieman et al. 2008). AIMAH is a heterogeneous disease that has received different names since its original description by Kirschner et al. (1964). Recently, it has been shown that AIMAH is not truly corticotropinindependent, because the regulation of cortisol secretion is exerted in part by ectopic production of corticotropin by clusters of adrenal cells, which in turn can be modulated by aberrant $G$ protein-coupled membrane receptors (Louiset et al. 2013) to stimulate cortisol production. Based on these data, the authors suggested a designation of the disease as bilateral macronodular adrenal hyperplasia (BMAH; Lacroix 2013, Louiset et al. 2013). Alencar et al. (2014) described a large Brazilian family with AIMAH, in which the affected members showed distinct disease patterns on a patient-by-patient basis (i.e. bilateral vs unilateral adrenal macronodules). For these reasons, we hereafter refer to the disorder as primary macronodular adrenal hyperplasia (PMAH; Fig. 1) instead of AIMAH or BMAH.

Published by Bioscientifica Ltd 
PMAH is usually characterized by functioning adrenal macronodules and variable cortisol secretion, and is generally identified as incidental bilateral adrenal hyperplasia in radiological images or during the evaluation of CS (Hsiao et al. 2009, Lacroix 2009). However, the asymmetric/asynchronous involvement of only one adrenal gland can also occur in PMAH (Alencar et al. 2014), making disease diagnosis a challenge. Subclinical CS is the most common clinical manifestation of PMAH, whereas classical CS is observed during the fifth and sixth decades of life, corresponding to a later age of onset than other types of CS (Lacroix \& Bourdeau 2005, Newell-Price et al. 2006, Lacroix 2009). Reports of familial clustering have been described in the last several years, suggesting that familial PMAH may be inherited in an autosomal dominant manner (Findlay et al. 1993, Minami et al. 1996, Imohl et al. 2002, Miyamura et al. 2002, Nies et al. 2002, Lee et al. 2005, Vezzosi et al. 2007, Watson et al. 2007, Gagliardi et al. 2009, Alencar et al. 2014). However, the sporadic form of PMAH (i.e. not associated with any

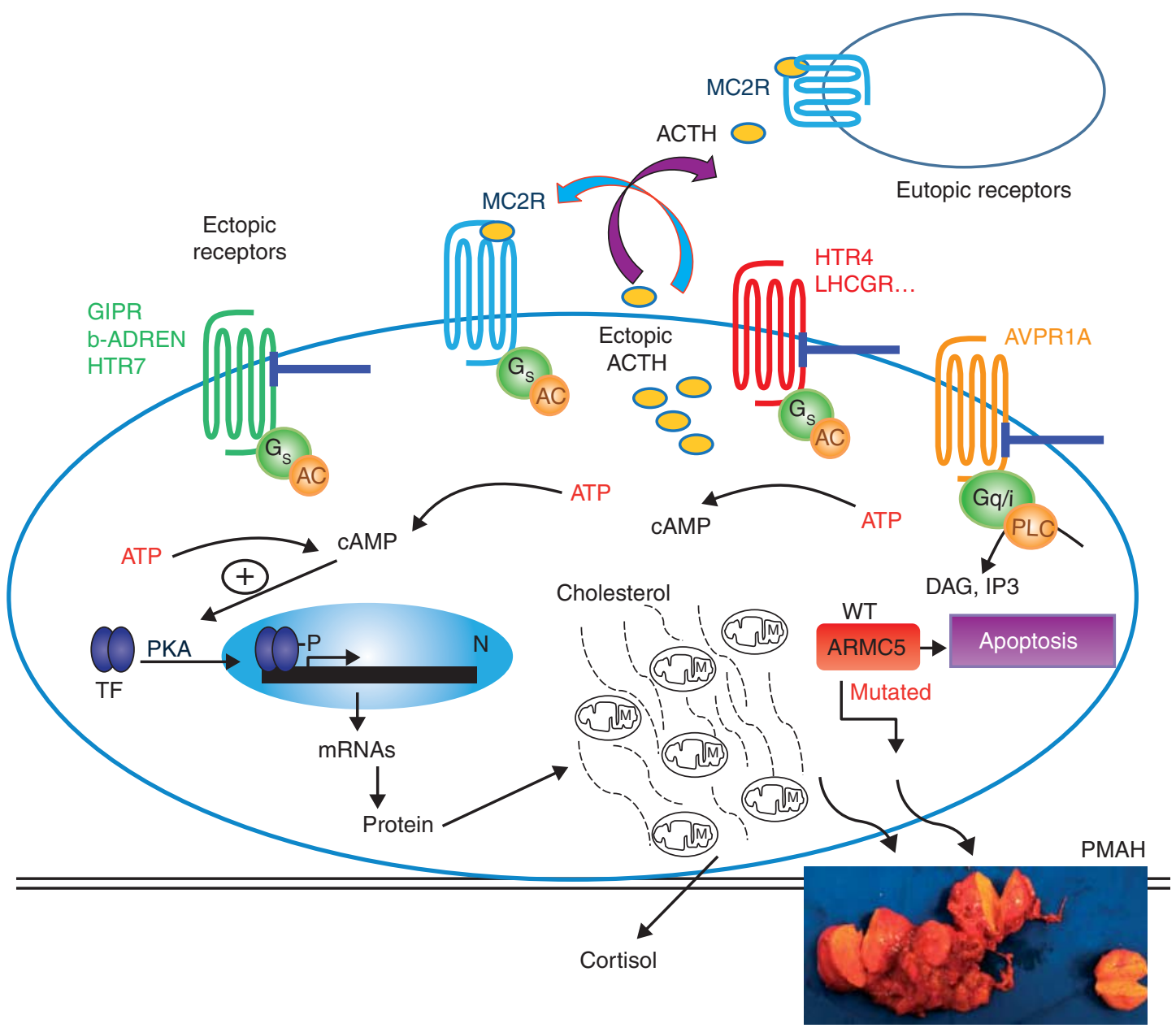

\section{Figure 1}

The main mechanism for PMAH development. The MC2R is a $G$ proteincoupled receptor of the ACTH, expressed in adrenal zona fasciculata. Abnormal regulation of the adrenal cortex as mediated by aberrant hormone receptors. Various hormones, including gastric inhibitory peptide (GIP), epinephrine (E), norepinephrine (NE), luteinizing hormone (LH), human chorionic gonadotropin (hCG), serotonin, and vasopressin, can bind to their respective aberrant membrane receptors (ectopic or eutopic) coupled to assorted $\mathrm{G}$ proteins $(\mathrm{Gs}, \mathrm{Gi}$, and $\mathrm{Gq}$ ), thereby determining the activation of adenylate cyclase (AC)-mediated signaling pathways by CAMP and protein kinase A (PKA). Ectopic ACTH acts on autocrine/paracrine regulatory mechanisms on $\mathrm{MC} 2 \mathrm{R}$ to increase cortisol production after
(C) 2015 Society for Endocrinology Printed in Great Britain stimulus of abnormal receptor. The activation of this pathway leads to phosphorylation of a number of transcription factors (TFs), culminating in the expression of steroidogenic enzymes during cortisol synthesis in the adrenal glands, as well as hyperplasia. The inactivating mutations of ARMC5 prevent its pro-apoptotic function probably involved in adrenal hyperplasia; however, this mechanism is unclear. MC2R, melanocortin 2 receptor; CYP11A1, cholesterol desmolase; CYP11B1, 11 -hydroxylase; CYP17, 17 $\alpha$-hydroxylase; CYP21A2, 21-hydroxylase; DAG, diacylglycerol; IP3, inositol triphosphate; $\mathrm{M}$, mitochondrion; N, nucleus; PLC,

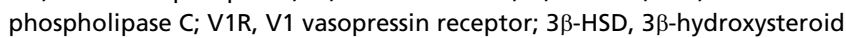
dehydrogenase; ARMC5, armadillo repeat-containing 5.

Published by Bioscientifica Ltd 
family history or genetic defect) appeared to be most common; nevertheless, the actual prevalence of familial vs sporadic disease is unknown, because active research on the index case's relatives was not a routine practice before the recent descriptions of a causative genetic factor for this disease (Assie et al. 2013, Alencar et al. 2014, Faucz et al. 2014, Gagliardi et al. 2014). Recent studies have now indicated that PMAH is more frequently genetically determined than previously believed (see section 'Participation of a new gene, ARMC5, in PMAH').

\section{Molecular mechanisms involved in PMAH}

Over the last two decades, different studies support that multiple molecular mechanisms may be involved in the pathogenesis of PMAH, suggesting that it may be a heterogeneous group of diseases that have a common presentation. In the following sections, we highlight the molecular abnormalities that have been proposed to be involved in PMAH pathogenesis (Fig. 1).

\section{Activating mutations in the melanocortin 2 receptor gene}

Under normal conditions, ACTH is the main regulator of cortisol and androgen synthesis in the adrenal cortex. ACTH exerts its actions through the melanocortin 2 receptor (MC2R), which belongs to the family of G protein-coupled receptors (GPCRs), also called seven transmembrane domain receptors. The cytoplasmic carboxy-terminal domain of MC2R interacts with various other protein receptors. In its inactivated state, the stimulatory G protein of MC2R is a heterotrimer formed by two alpha subunits $(\alpha)$ attached to a molecule of GDP, along with one beta subunit ( $\beta$ ) and one gamma subunit $(\gamma)$. Activation of the $G$ protein involves the exchange of GDP for GTP.

The MC2R gene (Online Mendelian Inheritance in Man (OMIM) database number 607397) is located on chromosome 18p11.21. MC2R activation is the first step in the stimulation of the cAMP/protein kinase A (PKA) downstream signaling pathway, and every step in this pathway may be affected by the activation of MC2R. So far, only two patients with activating $M C 2 R$ mutations have been identified, and only one of these patients was diagnosed with PMAH. Swords et al. (2002) performed an in vitro functional study demonstrating that the p.Phe278Cys $M C 2 R$ mutation, previously described as homozygous in a patient with $\mathrm{PMAH}$, determined the increase in MC2R protein basal activity/cAMP elevation and inhibited MC2R desensitization/internalization.
In another in vitro functional study, mutations at two concomitant receptor sites (p.Cys21Arg and p.Ser247Gly) constitutively activated the MC2R. These latter mutations occurred in the same allele in a patient with known hypersensitivity to ACTH (Hiroi et al. 1998, Swords et al. 2004). In both of the above patients, germline $M C 2 R$ mutations were also found.

The hypothesis that an activating $M C 2 R$ mutation could lead to constitutive activation of the downstream cAMP/PKA signaling pathway and the consequent autonomy of the adrenal gland was previously investigated (Latronico et al. 1995, Swords et al. 2002). However, later studies have shown that this is an extremely rare causative factor of PMAH (Fragoso et al. 2003, Alencar et al. 2014).

\section{Abnormal regulation of the adrenal cortex by aberrant hormone receptors}

The concept of abnormal hormone receptors in the adrenal gland was first proposed in 1971, by Schorr \& Ney (1971). These investigators conducted an in vitro analysis with primary cells derived from a transplantable rat adrenal carcinoma and showed that corticosterone was produced in response to three adenylate cyclase-activating agents: ACTH, catecholamine, and thyroid-stimulating hormone. Subsequent in vitro studies demonstrated functional coupling of membrane receptors for additional hormones in adrenocortical adenomas/carcinomas in higher animals, including humans (Lacroix et al. 2001, Antonini et al. 2004). Hamet et al. (1987) described the case of a patient with CS secondary to an adrenal adenoma, who presented with cortisol synthesis associated with food intake. From this point onward, the concept of aberrant hormone receptors began to gain clinical significance.

Some years later, two independent research groups demonstrated normal cortisol production in association with oral food intake in some subjects with PMAH (Lacroix et al. 1992, Reznik et al. 1992). In these PMAH patients, the hypercortisolism was triggered by the gastrointestinal hormone, gastric inhibitory peptide or glucose-dependent insulinotropic peptide (GIP). Since then, a high proportion of PMAH cases and a lesser proportion of adrenal adenoma cases have been documented, in which the patients presented cortisol release stimulated by hormones other than pituitary-ACTH (Lacroix et al. 1993, 2010, Christopoulos et al. 2004). However, it is not entirely clear whether the expression of these receptors is primarily responsible for PMAH pathogenesis, or is merely

Published by Bioscientifica Ltd. 
a secondary phenomenon resulting from cell proliferation state and dedifferentiation. In addition, no genetic abnormalities have been found in the coding or promoter regions of aberrant hormone receptor genes.

Some investigations support the aberrant expression of G-protein receptors as an initial and essential event in the pathogenesis of PMAH (Lacroix et al. 2004). Consistent with this hypothesis, aberrant receptors are almost universally present in PMAH, and even at the early stages of the disease (Bertherat et al. 2005, Libe et al. 2010). Furthermore, PMAH-like steroidogenesis can take place in vitro after hormone stimulation (Bertherat et al. 2005). Moreover, the temporal relationship between documented hypercortisolism and high levels of luteinizing hormone (LH)/human chorionic gonadotropin (hCG) during pregnancy and menopause in certain patients, and transfection experiments of GIP or the LH/hCG receptor into the adrenal cells of animal hosts, convincingly support a connection between gland hyperplasia and hypercortisolism in vivo (Lacroix et al. 1999, Mazzuco et al. 2006a,b).

On the other hand, it is possible that the presence of aberrant receptors is a secondary event resulting from cell proliferation and dedifferentiation rather than a decisive causative factor (Bourdeau \& Stratakis 2002). Supporting this idea is the fact that the in vivo inhibition of specific aberrant receptors using $\beta$ adrenergic antagonists or suppression of endogenous LH using leuprolide acetate: these therapies were able to control the hypercortisolism, but have never reduced the size of the macronodular adrenal hyperplasia (Lacroix et al. 1999, Feelders et al. 2003). Moreover, Swords et al. (2005) demonstrated that increased expression of an aberrant GIP receptor can also present in adrenal hyperplasia secondary to ACTHdependent CS and that cultured adrenal cells derived from affected patients respond to in vitro stimulation with GIP, suggesting that chronic adrenal stimulation with ACTH and constitutive activation of the MC2R downstream signaling pathway may induce aberrant expression of the GIP receptor. However, these findings were not confirmed by Antonini et al. (2006), who failed to demonstrate significant expression of GIP receptor in patients with chronic Cushing's disease undergoing bilateral adrenalectomy. Therefore, the role of the aberrant expression of GIP receptor as a causative factor of PMAH remains unclear.

Starting with the assumption that aberrant hormone receptors play a key role in the initiation and progression of PMAH, one might expect that the affected individuals belonging to the same family would express the same type of aberrant receptors. In certain families, specific aberrant GPCR including vasopressin, $\beta$-adrenergic, and 5HT4 receptors were found in all members of patients affected with PMAH (Miyamura et al. 2002, Lee et al. 2005, Vezzosi et al. 2007). In contrast, this was not found in members of the largest known family with PMAH, residing in Brazil (Alencar et al. 2014). Interestingly, cortisol production in response to assorted stimuli showed a lack of uniformity in the family members, despite their common pedigree. Furthermore, the intensity and frequency of patient responses were not related to the size or number of adrenal nodules in each affected individual, or to the degree of prior hypercortisolism (Alencar et al. 2014).

\section{Heterozygous gsp point mutations}

The gene encoding the alpha subunit of stimulatory G proteins (GNAS, OMIM 139320) is located on chromosome 20q13.32 (Weinstein et al. 2004). McCune-Albright syndrome (MAS) is caused by post-zygotic (somatic) activating mutations in this gene. These heterozygous point mutations are also termed gsp mutations and determine the loss of intrinsic GTPase activity of the alpha subunit, with subsequent constitutive activation of adenylate cyclase (Antonini et al. 2004, Brown et al. 2010).

Clinical manifestations of MAS are variable and depend mainly on the distribution of somatic mosaic mutations in the affected tissues. The syndrome presents with a classic triad of polyostotic fibrous dysplasia, 'café au latté' skin spots, and isosexual, gonadotropinindependent precocious puberty (Brown et al. 2010). Clinical variations on the classic triad can occur together with other endocrine and non-endocrine abnormalities. Bilateral adrenal hyperplasia and CS may accompany MAS, in young children with MAS, but this is not common and is characterized by adrenal nodules carrying the $g s p$ mutation and internodular atrophy of nonaffected adrenal cortex (Weinstein et al. 2004, Brown et al. 2010).

Fragoso et al. (2003) identified two distinct gsp somatic mutations affecting arginine residues in codon 201 of GNAS in few patients with PMAH, but the patients had no other typical manifestations of MAS. Subsequently, Hsiao et al. (2009) reported gsp somatic mutation in one additional patient with PMAH. Such cases might represent variations of MAS. Alternatively, they might characterize late $g s p$ somatic mutations, given that similar mutations have been described outside the context of MAS (e.g. together with acromegaly, thyroid cancer, and ovarian

Published by Bioscientifica Ltd. 
and testicular neoplasms; Antonini et al. 2004, Hsiao et al. 2009). On the other hand, an additional study failed to observe gsp mutations in PMAH (Christopoulos et al. 2005). Possibly, technical variations in the methodologies employed for the investigation of $g s p$ mutations could explain the discrepancy in these published findings.

Based on strong previous evidence implying that increased cAMP signaling is sufficient for cell proliferation and cortisol production, we surmise that these somatic activating mutations in GNAS are probably sufficient for macronodule formation and the hypercortisolism status (Lania et al. 2006, Meoli et al. 2008, de Joussineau et al. 2012).

\section{Association between PMAH and multiple endocrine neoplasia type 1}

Multiple endocrine neoplasia type 1 (MEN1) is a complex genetic syndrome caused by mutation in the tumor suppressor gene, MEN1 (OMIM 613733), which is located on chromosome 11q13.1. The MEN1 gene product is a protein called menin, which directly interacts with DNA and a number of other proteins and transcription factors (TFs). In this way, menin directly and indirectly regulates the cell cycle; inhibits cell proliferation; participates in DNA repair; interacts with the JunD proto-oncogene to inhibit its transcriptional activity and consequently cell growth; and performs various additional functions not listed here (Balogh et al. 2006). The MEN1 gene is transmitted in an autosomal dominant fashion and shows variable expression with age. The ensuing genetic syndrome is typified by its association with hyperparathyroidism, pituitary adenomas, and pancreatic islet tumors. Other manifestations may also be present and encompass adrenocortical lesions, lipomas, facial angiofibromas, collagenomas, duodenal gastrinomas, thyroid tumors, carcinoid tumors, and meningiomas (Thakker 2010, Newey \& Thakker 2011).

Adrenocortical lesions are relatively frequent in MEN1, and bilateral enlargement of the adrenal glands is documented in up to $21 \%$ of patients (Skogseid et al. 1992, Lacroix \& Bourdeau 2005). The pathophysiology of adrenocortical changes in MEN1 is not yet understood. According to a model proposed by Knudson for tumor development (Knudson's two-hit model), the initially unmutated MEN1 allele might be expected to generate a somatic inactivation in the hyperplastic adrenal gland; however, this apparently is not the case. Unlike other tumors associated with MEN1, loss of heterozygosity (LOH) has not been demonstrated among adrenocortical lesions (Skogseid et al. 1992, Costa et al. 2011). Furthermore, somatic or germline mutations are not found in MEN1 patients in the absence of concomitant PMAH. Some cases of PMAH with CS were found to have MEN1 or MEN1-like syndrome (hyperparathyroidism, insulinomas, and/or pituitary tumors) with or without MEN1 mutations (Sato et al. 2006, Lee et al. 2011, Yoshida et al. 2011).

\section{Association between PMAH and familial adenomatous polyposis coli}

Familial adenomatous polyposis coli (APC) is an inherited autosomal dominant condition linked to an inactivating germline mutation of the tumor suppressor gene, APC (OMIM 611731), located on chromosome 5q22.2 (Jang et al. 2010). The APC protein has multiple domains, through which it interacts with a host of other proteins, including $\beta$-catenin, axin, and microtubule-associated proteins. Through these interactions, APC exerts numerous activities, including inhibition of the canonical Wnt signaling pathway, control of cell proliferation and differentiation, regulation of cell adhesion and migration, and stabilization of chromosome segregation (Aoki \& Taketo 2007).

The bi-allelic inactivation of APC results in the constitutive activation of $\beta$-catenin and consequently the canonical Wnt signaling pathway, predisposing patients to tumorigenesis (Berthon et al. 2012). Familial APC is characterized by numerous adenomatous polyps in the colon and the rectum, beginning at the second and third decade and continuing throughout life. Colorectal carcinomas develop with progression of the disease, and have an incidence of nearly $100 \%$ after 40 years in the absence of adequate treatment (Groen et al. 2008, Hosogi et al. 2009). Certain intestinal manifestations occur more frequently in individuals with familial APC, such as papillary thyroid carcinomas, hepatoblastomas, brain tumors, pancreatic carcinomas, adrenocortical lesions, desmoid tumors, osteomas, epidermoid cysts, fibromas, lipomas, and congenital hypertrophy of the retinal pigment epithelium (Gaujoux et al. 2010).

Adrenocortical lesions (adenomas, carcinomas, and PMAH) occur two to four times more frequently in patients with familial adenomatous polyposis than in normal controls (Groen et al. 2008, Berthon et al. 2012). These lesions usually reveal a bi-allelic inactivation of $A P C$, namely, the presence of germinal and somatic mutations in adrenal tissue, in accordance with the

Published by Bioscientifica Ltd. 
proposed Knudson model (Blaker et al. 2004, Hosogi et al. 2009, Gaujoux et al. 2010, Berthon et al. 2012). In a previous study, only one patient with familial adenomatous polyposis and PMAH failed to display LOH of APC in adrenal hyperplasia (Yamakita et al. 1997). Ample experimental evidence, including that provided by animal models, has indicated that canonical Wnt signaling participates in adrenal tumorigenesis. Therefore, this same signaling pathway might factor in the pathophysiology of PMAH (Berthon et al. 2012). So far, germline and somatic mutations in the APC gene have been only described in the context of PMAH associated with familial adenomatous polyposis (Hsiao et al. 2009).

\section{Association between PMAH and hereditary leiomyomatosis and renal cell carcinoma}

Hereditary leiomyomatosis and renal cell carcinoma (HLRCC) is an autosomal dominant genetic syndrome caused by inactivating mutations of the tumor suppressor gene, fumarate hydratase (FH or OMIM 136850), found on chromosome 1q43 (Sudarshan et al. 2007). This gene encodes an enzyme that converts fumarate to malate in the tricarboxylic acid cycle (also known as the Krebs cycle). With the inactivation of $\mathrm{FH}$, fumarate accumulates inside the mitochondria. The excess substrate overflows into the cytoplasm, inhibiting a group of prolyl hydroxylases. Inhibition of these enzymes determines the activation status of a TF termed hypoxia-induced factor 1 (HIF1), favoring increased glycolytic activity, neovascularization, and downregulation of cellular apoptosis, all important features of tumorigenesis (King et al. 2006, Badeloe \& Frank 2009).

HLRCC is characterized by cutaneous leiomyomas, leiomyosarcomas, uterine leiomyomas, and papillary renal carcinomas (Matyakhina et al. 2005). Bi-allelic inactivation of the $F H$ gene generally accompanies this tumor-associated genetic syndrome, along with loss of the normal allele. Bilateral adrenal lesions are occasionally observed in isolated cases of HLRCC (Matyakhina et al. 2005, Lehtonen et al. 2006). In one of these cases, the bilateral lesions accompanied $\mathrm{LOH}$ of the $F H$ gene in the hyperplastic adrenal gland (Matyakhina et al. 2005). Recently, four bilateral adrenal lesions have been found among 255 cases of HLRCC (Shuch et al. 2013).

There are few reports to date of mutations in the $F H$ gene, and PMAH in affected individuals occurred only within the context of HLRCC (Hsiao et al. 2009). Although a fortuitous relationship cannot be excluded, HLRCC may be added to the list of monogenic disorders reportedly associated with the development of hyperplastic adrenal nodules. Thus, $F H$ may be considered as a candidate gene for heterogeneous PMAH (Matyakhina et al. 2005).

\section{Signaling pathways and genetic alterations potentially related to PMAH}

Several studies have analyzed gene expression in AIMAH/PMAH so as to investigate prospective signaling pathways and potentially disease-related molecular mediators.

Bourdeau et al. (2004) evaluated the gene expression profile in PMAH by conducting a microarray analysis of cDNA derived from adrenal tissue samples of eight patients with the disorder. The investigators paid particular attention to the activation of signaling pathways downstream of HIFs and Wnt, in addition to the aberrant expression of the GIP receptor. Notably, previous work showed that HIF- and Wnt-mediated pathways are hyperactivated in two distinct genetic syndromes related to PMAH: HLRCC and familial adenomatous polyposis respectively (Aoki \& Taketo 2007, Sudarshan et al. 2007). According to the results of Bourdeau et al. (2004), the PKA signaling pathway might also be altered in $\mathrm{PMAH}$, as it is in primary pigmented nodular adrenocortical disease (PPNAD; Bourdeau et al. 2004). Furthermore, Bourdeau et al. (2004) found that selected genes encoding steroidogenic enzymes were underexpressed in PMAH patients, strengthening the hypothesis of inefficient PMAH steroidogenesis.

In another investigation consisting of eight patients with AIMAH/PMAH and aberrant expression of the GIP receptor, Antonini et al. (2006) further examined the expression of several genes related to steroidogenesis and PKA signaling. Similar to the work of others, this study revealed paradoxical underexpression rather than overexpression of steroidogenesis-related genes. In this study, the PKA signaling pathway also appeared to be hypoactivated (Bourdeau et al. 2004).

Lampron et al. (2006) conducted a study of gene expression on a genome-wide scale (i.e. whole-genome expression profiling) involving five patients with PMAH and aberrant expression of the GIP receptor, and five patients with ACTH-dependent adrenal hyperplasia. The genetic material was extracted directly from each patient's hyperplastic adrenal gland. Among the patients with PMAH, hypoexpression of genes related to steroidogenesis was again demonstrated. A French research group also observed abnormal gene overexpression of several not yet described transmembrane GPCRs in a number of PMAH

Published by Bioscientifica Ltd. 
subjects (Assie et al. 2010). Despite these findings, hypo/hyperexpression of genes has not been convincingly and directly linked with the main cAMP/PKA signaling pathway potentially related to PMAH.

Bourdeau et al. (2006) conducted a further study with the aim of specifically assessing whether the PKA signaling pathway was altered in PMAH. Although no mutations were found in the regulatory subunit of PKA type 1A (PRKAR1A) gene, which is often described as mutated in PPNAD and the Carney complex gene (Stratakis \& Boikos 2007), PKA activity was higher in PMAH compared with normal adrenal glands. Based on their findings, the investigators proposed that altered expression of the PKA regulatory subunits might lead to increased kinase activity.

\section{Additional whole-genome expression profiling in PMAH}

In another whole-genome expression profiling study, Almeida et al. (2011) evaluated different details of adrenal nodules from the same patient with PMAH. Gene expression was analyzed in each adrenal nodule on a genome-wide scale, and chromosomal disorders were assessed by comparative genomic hybridization microarray analysis with relevant oligonucleotides. Regions of chromosomal gain occurred more frequently in major adrenal nodules, with more than half of the overerexpressed, amplified genes located in such portions of the genome. The expression pattern of some genes also suggested the activation of Wnt signaling, in agreement with the previously discussed findings of Bourdeau et al. (2004).

Recent studies have demonstrated the role of Wnt signaling in the development of adrenal hyperplasia and adrenal tumor (Almeida et al. 2012, Berthon et al. 2012). Almeida et al. (2011) also reported that, although the genes of the catalytic subunits of PKA are overexpressed, enzyme activity tended to be lower in larger vs smaller nodules. Furthermore, the authors suggested that the increased size of the adrenal nodules was related to the progressive accumulation of chromosomal alterations and the activation of signaling pathways usually involved in tumorigenesis.

Gagliardi et al. (2012) conducted a study to evaluate genome-wide expression profiles in individuals with familial PMAH. Transcriptomes obtained from the adrenal glands of three affected brothers were compared with those obtained from the normal glands of two unaffected brothers. Unlike in previous investigations, this study revealed no significant hypoexpression of genes encoding steroidogenic enzymes. The authors initially observed an increase in cortisol levels in the three PMAH subjects after in vivo stimulation with vasopressin. Moreover, the receptor genes of arginine vasopressin were hyperexpressed in the hyperplastic adrenal glands. However, it was not possible to identify those genes related to aberrant expression of pertinent receptors or the associated mechanisms, and contrary to the expected results, the signaling pathways of the arginine vasopressin receptor were not hyperexpressed.

Finally, Gagliardi et al. (2012) showed that some of the genes differentially expressed in familial PMAH were previously linked with tumorigenesis. Thus, PMAH and malignant adrenocortical tumors apparently share certain signaling pathways, as previously proposed by Almeida et al. (2011).

Assie et al. (2010) employed cDNA microarray analysis to evaluate the whole-genome expression of more than 800 transmembrane GPCRs in a group of 18 patients with PMAH. The authors demonstrated the expression of several transmembrane receptors in hyperplastic adrenal glands not previously described in PMAH. In addition, several hyperplastic glands expressed receptors with a distinct frequency not observed in normal glands. Thus, it was difficult to assign the presence of a specific hormone receptor to hyperplasia. In this same study, the adrenal glands of CS patients also sometimes expressed GPCRs, even when chronically stimulated by ACTH. This latter finding, in a way, supports the hypothesis that aberrant expression of receptors in PMAH may be an epiphenomenon of disease pathophysiology.

\section{MicroRNA profile of PMAH}

MicroRNAs (miRNAs) are RNA molecules composed of about 22 nucleotides directed against protein coding and noncoding regions that act as potent post-transcriptional regulators of gene expression under physiological as well as pathological conditions. miRNAs bind to specific regions of mRNA, thereby promoting mRNA degradation and/or inhibiting protein translation (Ricarte Filho \& Kimura 2006, Pritchard et al. 2012). Bimpaki et al. (2010) conducted a study of miRNAs in ten patients with PMAH, aiming to define the miRNA profile of the disease. Thirty-seven miRNAs with altered expression (low or high) were identified in the hyperplastic adrenal gland of PMAH patients. Two of these miRNAs especially caught our attention: miR-210 (with increased expression) and miR-200b (with reduced expression). miR-2010 transcription is stimulated by the HIF-mediated signaling cascade, while miR-200b acts as a regulator of matrin 3 protein translation, where matrin 3 is a nuclear matrix component

Published by Bioscientifica Ltd 
and a substrate for PKA. Hence, miR-210 and miR-200b potentially play roles in PMAH development and/or progression.

\section{Ectopic expression of corticotropin in PMAH}

A few studies have been published over the last two decades, showing that affected adrenal glands display abnormal expression of ectopic corticotropin in PMAH. This implies that ectopic production of ACTH might induce adrenocortical hyperplasia and cortisol secretion (Pereira et al. 2001, Lefebvre et al. 2003, Mazzuco et al. 2007, Iwata et al. 2012).

A recent extensive study from Louiset et al. (2013) has revealed that the cortisol secretion by CS-associated adrenal hyperplastic macronodules was apparently regulated by ectopic ACTH. Ectopic АCTH was in turn produced by a cluster of steroidogenic adrenal cells acting in an autocrine/paracrine manner. The mRNA encoding the corticotropin precursor, pro-opiomelanocortin, was detected in all hyperplastic adrenal samples investigated. In addition, convertase type 1 expression was detected in adrenal cells, suggesting that the cells may generate bioactive corticotropin. Immunohistochemical staining confirmed the distribution of ACTH throughout the cells, and corticotropin secretion was observed at a higher concentration in adrenal vs peripheral veins from two patients with PMAH.

Louiset et al. (2013) examined the effects of classic regulators of pituitary ACTH secretion on the release of ectopic corticotropin by hyperplastic explants, but failed to uncover any significant action of the regulators. Interestingly, the release of adrenal corticotropin was stimulated by ligands of aberrant membrane receptors expressed by hyperplastic tissues (i.e. GIP, serotonin, and hCG). The corticotropin-receptor antagonists, corticostatin, and corticotropin 7-38 inhibited cortisol secretion by $40 \%$ in tissues that contained aberrant GPCRs. Thus, in vitro evidence supports the hypothesis that cortisol production is controlled by aberrant hormone receptors and ectopic corticotropin produced within adrenocortical tissue (Louiset et al. 2013). The concept of aberrant GPCR regulating autocrine ACTH production is also supported by the in vivo observation that in patients with GIPdependent PMAH, cortisol levels can be low during fasting in the morning when circulating GIP is low and ACTH either from pituitary or from hyperplastic adrenal tissues is low (Lacroix et al. 2009). ACTH production appears to be present in PMAH tissues irrespective of the presence of armadillo repeat-containing protein 5 (ARMC5) mutation (see later).
Additional work indicated that PMAH tissues also produce serotonin, vasopressin, glucagon, and other factors that further contribute to the paracrine regulatory loops of cortisol secretion and cell proliferation (Lefebvre et al. 2013). These findings bolster the proposal that paracrine adrenal production of ACTH is central to the cortisol-facilitated regulation of PMAH. Preclinical and clinical studies are therefore required to examine whether novel drugs directed against the ACTH receptor (MC2R) can reverse excessive cortisol secretion in affected patients (Lacroix 2013).

\section{Participation of a new gene, ARMC5, in PMAH}

ARMC5 makes part of a large family of proteins, characterized by the presence of tandem repeats of an amino acid motif. This family is highly conserved through evolution in eukaryotic organisms (from yeast to human). $\beta$-catenin is a member of the armadillo protein family, and is known to be involved in adrenocortical development and adrenal disorders, such as adenomas and carcinomas (Huber et al. 1997, Tewari et al. 2010).

The most important recent finding in this field is the discovery of germline mutations of ARMC5 in 50\% of patients with apparently sporadic $\mathrm{PMAH}$, and also in a large family with genetically transmitted PMAH (Assie et al. 2013, Alencar et al. 2014). Germline mutations in the ARMC5 gene have been later confirmed in apparent sporadic and familial PMAH cases in up to $50 \%$ of the individuals investigated (Alencar et al. 2014, Faucz et al. 2014, Gagliardi et al. 2014). These mutations were uncovered by using single-nucleotide polymorphism arrays, linkage analyses, and whole-exome sequencing. The ARMC5 gene is located on chromosome 16p11.2 and has an unknown function. A second (somatic) mutational event (either 16p LOH or a second somatic mutation in the coding region of the gene) was identified, suggesting that ARMC5 may be a tumor suppressor gene. Consistent with that, an in vitro study has demonstrated that ARMC5 transfection to the adrenocortical cancer cell line H295R induces apoptosis (Assie et al. 2013). ARMC5 has no apparent link to the cAMP pathway, but its inactivation decreases the expression of both MC2R and various steroidogenic enzymes (Assie et al. 2013). Previous studies found that beyond a certain common event, such as ectopic expression of GIP receptors or germline ARMC5 mutations in diffuse hyperplasia, several somatic genetic events occurred in the different macronodules. Thus, the second somatic ARMC5 mutation or another second hit may contribute to the progression of macronodules.

Published by Bioscientifica Ltd. 
However the function of ARMC5 remains unknown as do the mechanisms of the inactivating mutations of ARMC5 involved in development of adrenal macronodular hyperplasia (Berthon \& Stratakis 2014).

Interestingly, six out of 11 (54\%) first-degree relatives of seven probands carried a germline ARMC5 mutation; five of these showed at least one nodule on computed tomography (CT) scans, coupled with increased cortisol secretion in three cases (Alencar et al. 2014). One elderly patient (76 years of age) harboring a germline mutation did not show any abnormal hormonal results and showed a normal adrenal CT scan. It is possible that this patient did not have a second-hit ARMC5 molecular event in the adrenal gland, indicative of incomplete penetrance of PMAH (Alencar et al. 2014). Further familial studies will be useful to clarify the clinical penetrance of ARMC5 mutations.

The search for ARMC5 or other responsible genes should allow familial screening through a simple blood test, permitting the identification of at-risk individuals who would probably benefit from further evaluations (Assie et al. 2013, Lacroix 2013, Alencar et al. 2014).

\section{Other molecular mechanisms of PMAH}

Cao et al. (2014) investigated genetic lesions in adrenal CS by using whole-exome sequencing of DNA isolated from adrenocortical adenomas, PMAH lesions, and adrenocortical oncocytomas. The authors identified two novel mutations in the highly conserved methyltransferase domain of DOT1L, a histone H3 lysine 79 (H3K79) methyltransferase. DOT1L regulates gene transcription and cell proliferation, and also mediates cell transformation in mixed lineage-rearranged leukemia. In addition, the histone deacetylase gene HDAC9 was mutated in one PMAH case, while the affected individuals did not show either ARMC5 or GSP mutations. These data show that deregulated chromatin modifications might contribute to tumorigenesis in PMAH. Further investigations of these new mutations are required to elucidate their frequency and relevance in the molecular pathogenesis of PMAH.

Beuschlein et al. (2014) recently explored the constitutive activation of the PKA catalytic subunit in several forms of adrenal CS by using genome-wide copy-number analysis. The authors identified germline PRKACA gene duplications in a mother-son set of affected individuals with mild CS due to PMAH. The adrenal tissue of the subjects with PRKACA duplications exhibited higher PKA C alpha mRNA and protein levels in comparison with tumor tissue samples from patients without any known genetic defect. In addition, immunohistochemical experiments confirmed the higher expression levels of the PKA C alpha subunit in the adrenal glands of PMAH subjects. The authors concluded that the genetic variants of the PKA catalytic subunit in both adrenal hyperplasia and adenomas of the adrenocortical cortex could lead to pituitary ACTH-independent CS. Interestingly, somatic GNAS mutations were recently identified in $5-17 \%$ of cortisol secreting adenomas. PKA catalytic subunit mutations in cortisol secreting adenomas were also confirmed by other group (Lee et al. 2011).

\section{The association between meningioma and PMAH: is it a coincidence or a new syndrome?}

Lee et al. (2005) described two siblings with PMAH and high expression of vasopressin V1b and V2 receptors in the adrenal glands. The authors also reported incidentally found parasagittal meningioma in the right parietaloccipital region in one sibling and a mass of size $3.0 \times 2.5 \mathrm{~cm}$ in the left anterior falx that was thought to be a meningioma in the other sibling.

In a preliminary investigation (Alencar et al. 2014), we have found typical images of intracranial meningiomas or a previous history of these tumors in $43 \%$ of the Brazilian family members (three out of seven evaluated patients) with germline ARMC5 mutations and PMAH. The meningioma occurred in patients with classical or subclinical CS (age ranged 26-53 years of age).

In contrast, meningiomas are incidentally diagnosed in only $0.9 \%$ of the general population after the fourth decade of life (Vernooij et al. 2007). Recently in Germany, in a member of a family with PMAH with intracranial meningothelial meningioma WHO grade I, a somatic frameshift mutation in ARMC5 (p.R502fs) was identified, corroborating that such mutations can be causative for the associated meningiomas (Elbelt et al. 2014). The ARMC5 gene is ubiquitously expressed in normal human tissues (http://www.genecards.org), further studies are needed to investigate the potential involvement of ARMC 5 mutations with occurrence of other neoplasias (Lacroix 2013).

\section{Discussion/summary}

CS is a challenging disease that results from chronic exposure to excessive levels of circulating cortisol. PMAH was initially regarded as a sporadic disease, but familial autosomal dominant forms are now recognized. The genetic origin of PMAH is supported by the bilateral

Published by Bioscientifica Ltd 
nature (in most cases) of the adrenal tumors and the propensity of the disease to run in families.

Germline mutations in the ARMC5 gene have been documented in apparent sporadic and familial PMAH cases in $>50 \%$ of the individuals investigated (Alencar et al. 2014, Faucz et al. 2014, Gagliardi et al. 2014). In functional work performed by Assie et al. (2013), ARMC5 was found to induce apoptosis in H295R adrenocortical carcinoma cells. In addition, ARMC5 gene inactivation was reportedly associated with a slow process of dedifferentiation in adrenocortical cells, concomitant with reduced expression of MC2R and steroidogenic enzymes. Of note, MC2R and steroidogenic enzymes are also frequently reduced in PMAH. The function of the ARMC5 protein is unknown, but these findings suggest that its gene belongs to the tumor suppressor family.

Also of note, adrenal cells in PMAH are relatively inefficient in terms of steroidogenesis, and a large adrenal size seems to be required to produce sufficient cortisol for the induction of clinical hypercortisolism.

Consideration of PMAH as a pituitary corticotropinindependent variant of CS has highlighted the aberrant expression of ACTH in cell clusters obtained from hyperplastic adrenal tissues. Furthermore, the release of ACTH is triggered by ligands of aberrant membrane receptors. Interestingly, intra-adrenal corticotropin apparently stimulates cortisol secretion through a complex autocrine/paracrine mechanism involving MC2R, suggesting that intra-adrenal ACTH participates in the pathogenesis of hypercortisolism. In addition, the confirmation of somatic ARMC5 mutation in meningioma tissue from a patient with PMAH suggests an additional role for this gene.

\section{Conclusions}

Recent molecular genetic investigations of PMAH provide new insights for future research on adrenal disorders. The identification of a genetic basis for PMAH is anticipated to permit earlier diagnosis and to improve the management of this disease. An international, collaborative task force would substantially facilitate the study of large patient cohorts with this familial disease, including appropriate follow-up and therapy for such individuals with this heterogeneous adrenal disease.

\section{Declaration of interest}

The authors declare that there is no conflict of interest that could be perceived as prejudicing the impartiality of this review.
Funding

This review did not receive any specific grant from any funding agency in the public, commercial or not-for-profit sector.

\section{Acknowledgements}

The authors would like to thank the staff of Laboratory of Hormone and Molecular Genetic LIM/42 of Hospital das Clinicas da Faculdade de Medicina of Sao Paulo University mainly Mirian Nish PhD for the support of genetic analysis.

\section{References}

Alencar GA, Lerario AM, Nishi MY, Mariani BM, Almeida MQ, Tremblay J, Hamet P, Bourdeau I, Zerbini MC, Pereira MA et al. 2014 ARMC5 mutations are a frequent cause of primary macronodular adrenal hyperplasia. Journal of Clinical Endocrinology and Metabolism 99 E1501-E1509. (doi:10.1210/jc.2013-4237)

Almeida MQ, Harran M, Bimpaki EI, Hsiao HP, Horvath A, Cheadle C, Watkins T, Nesterova M \& Stratakis CA 2011 Integrated genomic analysis of nodular tissue in macronodular adrenocortical hyperplasia: progression of tumorigenesis in a disorder associated with multiple benign lesions. Journal of Clinical Endocrinology and Metabolism 96 E728-E738. (doi:10.1210/jc.2010-2420)

Almeida MQ, Azevedo MF, Xekouki P, Bimpaki EI, Horvath A, Collins MT, Karaviti LP, Jeha GS, Bhattacharyya N, Cheadle C et al. 2012 Activation of cyclic AMP signaling leads to different pathway alterations in lesions of the adrenal cortex caused by germline PRKAR1A defects versus those due to somatic GNAS mutations. Journal of Clinical Endocrinology and Metabolism 97 E687-E693. (doi:10.1210/jc.2011-3000)

Antonini SR, Fragoso MC \& Lacroix A 2004 Clinical and molecular aspects of the ACTH-independent bilateral macronodular adrenal hyperplasia. Arquivos Brasileiros de Endocrinologia e Metabologia 48 620-636. (doi:10.1590/S0004-27302004000500006)

Antonini SR, Baldacchino V, Tremblay J, Hamet P \& Lacroix A 2006 Expression of ACTH receptor pathway genes in glucose-dependent insulinotrophic peptide (GIP)-dependent Cushing's syndrome. Clinical Endocrinology 64 29-36. (doi:10.1111/j.1365-2265.2005.02411.x)

Aoki K \& Taketo MM 2007 Adenomatous polyposis coli (APC): a multi-functional tumor suppressor gene. Journal of Cell Science 120 3327-3335. (doi:10.1242/jcs.03485)

Arnaldi G, Angeli A, Atkinson AB, Bertagna X, Cavagnini F, Chrousos GP, Fava GA, Findling JW, Gaillard RC, Grossman AB et al. 2003 Diagnosis and complications of Cushing's syndrome: a consensus statement. Journal of Clinical Endocrinology and Metabolism 88 5593-5602. (doi:10.1210/jc.2003-030871)

Assie G, Louiset E, Sturm N, Rene-Corail F, Groussin L, Bertherat J, Thomas M, Lefebvre H, Feige JJ, Clauser E et al. 2010 Systematic analysis of $\mathrm{G}$ protein-coupled receptor gene expression in adrenocorticotropin-independent macronodular adrenocortical hyperplasia identifies novel targets for pharmacological control of adrenal Cushing's syndrome. Journal of Clinical Endocrinology and Metabolism 95 E253-E262. (doi:10.1210/jc.2009-2281)

Assie G, Libe R, Espiard S, Rizk-Rabin M, Guimier A, Luscap W, Barreau O, Lefevre L, Sibony M, Guignat L et al. 2013 ARMC5 mutations in macronodular adrenal hyperplasia with Cushing's syndrome. New England Journal of Medicine 369 2105-2114. (doi:10.1056/ NEJMoa1304603)

Badeloe S \& Frank J 2009 Clinical and molecular genetic aspects of hereditary multiple cutaneous leiomyomatosis. European Journal of Dermatology 19 545-551. (doi:10.1684/ejd.2009.0749) 
Balogh K, Racz K, Patocs A \& Hunyady L 2006 Menin and its interacting proteins: elucidation of menin function. Trends in Endocrinology and Metabolism 17 357-364. (doi:10.1016/j.tem.2006.09.004)

Bertherat J, Contesse V, Louiset E, Barrande G, Duparc C, Groussin L, Emy P, Bertagna X, Kuhn JM, Vaudry H et al. 2005 In vivo and in vitro screening for illegitimate receptors in adrenocorticotropin-independent macronodular adrenal hyperplasia causing Cushing's syndrome: identification of two cases of gonadotropin/gastric inhibitory polypeptide-dependent hypercortisolism. Journal of Clinical Endocrinology and Metabolism 90 1302-1310. (doi:10.1210/jc.2004-1256)

Berthon A \& Stratakis CA 2014 From $\beta$-catenine to ARM-repeat proteins in adrenocortical disorders. Hormone and Metabolic Research 46 889-896. (doi:10.1055/s-0034-1389993)

Berthon A, Martinez A, Bertherat J \& Val P 2012 Wnt/ $\beta$-catenin signalling in adrenal physiology and tumour development. Molecular and Cellular Endocrinology 351 87-95. (doi:10.1016/j.mce.2011.09.009)

Beuschlein F, Fassnacht M, Assie G, Calebiro D, Stratakis CA, Osswald A, Ronchi CL, Wieland T, Sbiera S, Faucz FR et al. 2014 Constitutive activation of PKA catalytic subunit in adrenal Cushing's syndrome. New England Journal of Medicine 370 1019-1028. (doi:10.1056/NEJMoa1310359)

Bimpaki EI, Iliopoulos D, Moraitis A \& Stratakis CA 2010 MicroRNA signature in massive macronodular adrenocortical disease and implications for adrenocortical tumourigenesis. Clinical Endocrinology $\mathbf{7 2}$ 744-751. (doi:10.1111/j.1365-2265.2009.03725.x)

Blaker H, Sutter C, Kadmon M, Otto HF, Von Knebel-Doeberitz M, Gebert J $\&$ Helmke BM 2004 Analysis of somatic APC mutations in rare extracolonic tumors of patients with familial adenomatous polyposis coli. Genes, Chromosomes \& Cancer 41 93-98. (doi:10.1002/gcc.20071)

Bourdeau I \& Stratakis CA 2002 Cyclic AMP-dependent signaling aberrations in macronodular adrenal disease. Annals of the New York Academy of Sciences 968 240-255. (doi:10.1111/j.1749-6632.2002. tb04339.x)

Bourdeau I, Antonini SR, Lacroix A, Kirschner LS, Matyakhina L, Lorang D, Libutti SK \& Stratakis CA 2004 Gene array analysis of macronodular adrenal hyperplasia confirms clinical heterogeneity and identifies several candidate genes as molecular mediators. Oncogene 23 1575-1585. (doi:10.1038/sj.onc.1207277)

Bourdeau I, Matyakhina L, Stergiopoulos SG, Sandrini F, Boikos S \& Stratakis CA 2006 17q22-24 chromosomal losses and alterations of protein kinase A subunit expression and activity in adrenocorticotropin-independent macronodular adrenal hyperplasia. Journal of Clinical Endocrinology and Metabolism 91 3626-3632. (doi:10.1210/ jc.2005-2608)

Brown RJ, Kelly MH \& Collins MT 2010 Cushing syndrome in the McCuneAlbright syndrome. Journal of Clinical Endocrinology and Metabolism 95 1508-1515. (doi:10.1210/jc.2009-2321)

Cao Y, He M, Gao Z, Peng Y, Li Y, Li L, Zhou W, Li X, Zhong X, Lei Y etal. 2014 Activating hotspot L205R mutation in PRKACA and adrenal Cushing's syndrome. Science 344 913-917. (doi:10.1126/science.1249480)

Christopoulos S, Bourdeau I \& Lacroix A 2004 Aberrant expression of hormone receptors in adrenal Cushing's syndrome. Pituitary 7 225-235. (doi:10.1007/s11102-005-1083-7)

Christopoulos S, Bourdeau I \& Lacroix A 2005 Clinical and subclinical ACTH-independent macronodular adrenal hyperplasia and aberrant hormone receptors. Hormone Research 64 119-131. (doi:10.1159/ 000088818)

Costa MH, Domenice S, Toledo RA, Lourenco DM Jr, Latronico AC, Pinto EM, Toledo SP, Mendonca BB \& Fragoso MC 2011 Glucose-dependent insulinotropic peptide receptor overexpression in adrenocortical hyperplasia in MEN1 syndrome without loss of heterozygosity at the 11q13 locus. Clinics 66 529-533.

Elbelt U, Trovato A, Kloth M, Gentz E, Finke R, Spranger J, Galas D, Weber S, Wolf C, König K et al. 2014 Molecular and clinical evidence for ARMC5 tumor syndrome: concurrent inactivating germline and somatic mutations are associated with both primary macronodular adrenal hyperplasia and meningiomas. Journal of Clinical Endocrinology and Metabolism [in press]. (doi:10.1210/jc.2014-2648)

Faucz FR, Zilbermint M, Lodish MB, Szarek E, Trivellin G, Sinaii N, Berthon A, Libe R, Assie G, Espiard S etal. 2014 Macronodular adrenal hyperplasia due to mutations in an armadillo repeat containing 5 (ARMC5) gene: a clinical and genetic investigation. Journal of Clinical Endocrinology and Metabolism 99 E1113-E1119. (doi:10.1210/jc.2013-4280)

Feelders RA, Lamberts SW, Hofland LJ, van Koetsveld PM, Verhoef-Post M, Themmen AP, de Jong FH, Bonjer HJ, Clark AJ, van der Lely AJ et al. 2003 Luteinizing hormone (LH)-responsive Cushing's syndrome: the demonstration of LH receptor messenger ribonucleic acid in hyperplastic adrenal cells, which respond to chorionic gonadotropin and serotonin agonists in vitro. Journal of Clinical Endocrinology and Metabolism 88 230-237. (doi:10.1210/jc.2002-020621)

Findlay JC, Sheeler LR, Engeland WC \& Aron DC 1993 Familial adrenocorticotropin-independent Cushing's syndrome with bilateral macronodular adrenal hyperplasia. Journal of Clinical Endocrinology and Metabolism 76 189-191.

Fragoso MC, Domenice S, Latronico AC, Martin RM, Pereira MA, Zerbini MC, Lucon AM \& Mendonca BB 2003 Cushing's syndrome secondary to adrenocorticotropin-independent macronodular adrenocortical hyperplasia due to activating mutations of GNAS1 gene. Journal of Clinical Endocrinology and Metabolism 88 2147-2151. (doi:10.1210/jc. 2002-021362)

Gagliardi L, Hotu C, Casey G, Braund WJ, Ling KH, Dodd T, Manavis J, Devitt PG, Cutfield R, Rudzki Z et al. 2009 Familial vasopressin-sensitive ACTH-independent macronodular adrenal hyperplasia (VPs-AIMAH): clinical studies of three kindreds. Clinical Endocrinology 70 883-891. (doi:10.1111/j.1365-2265.2008.03471.x)

Gagliardi L, Ling KH, Kok CH, Carolan J, Brautigan P, Kenyon R, D'Andrea RJ, Van der Hoek M, Hahn CN, Torpy DJ et al. 2012 Genome-wide gene expression profiling identifies overlap with malignant adrenocortical tumours and novel mechanisms of inefficient steroidogenesis in familial ACTH-independent macronodular adrenal hyperplasia. Endocrine-Related Cancer 19 L19-L23. (doi:10.1530/ERC-11-0210)

Gagliardi L, Schreiber AW, Hahn CN, Feng J, Cranston T, Boon H, Hotu C, Oftedal BE, Cutfield R, Adelson DL et al. 2014 Armc5 mutations are common in familial bilateral macronodular adrenal hyperplasia. Journal of Clinical Endocrinology and Metabolism 99 E1784-E1792. (doi:10.1210/jc.2014-1265)

Gaujoux S, Pinson S, Gimenez-Roqueplo AP, Amar L, Ragazzon B, Launay P, Meatchi T, Libe R, Bertagna X, Audebourg A et al. 2010 Inactivation of the APC gene is constant in adrenocortical tumors from patients with familial adenomatous polyposis but not frequent in sporadic adrenocortical cancers. Clinical Cancer Research 16 5133-5141. (doi:10.1158/ 1078-0432.CCR-10-1497)

Groen EJ, Roos A, Muntinghe FL, Enting RH, de Vries J, Kleibeuker JH, Witjes MJ, Links TP \& van Beek AP 2008 Extra-intestinal manifestations of familial adenomatous polyposis. Annals of Surgical Oncology $\mathbf{1 5}$ 2439-2450. (doi:10.1245/s10434-008-9981-3)

Hamet P, Larochelle P, Franks DJ, Cartier P \& Bolte E 1987 Cushing syndrome with food-dependent periodic hormonogenesis. Clinical and Investigative Medicine 10 530-533.

Hiroi N, Yakushiji F, Shimojo M, Watanabe S, Sugano S, Yamaguchi N \& Miyachi Y 1998 Human ACTH hypersensitivity syndrome associated with abnormalities of the ACTH receptor gene. Clinical Endocrinology $\mathbf{4 8}$ 129-134. (doi:10.1046/j.1365-2265.1998.3971187.x)

Hosogi H, Nagayama S, Kanamoto N, Yoshizawa A, Suzuki T, Nakao K \& Sakai Y 2009 Biallelic APC inactivation was responsible for functional adrenocortical adenoma in familial adenomatous polyposis with novel germline mutation of the APC gene: report of a case. Japanese Journal of Clinical Oncology 39 837-846. (doi:10.1093/jjco/hyp093)

Hsiao HP, Kirschner LS, Bourdeau I, Keil MF, Boikos SA, Verma S, RobinsonWhite AJ, Nesterova M, Lacroix A \& Stratakis CA 2009 Clinical and genetic heterogeneity, overlap with other tumor syndromes, and atypical glucocorticoid hormone secretion in adrenocorticotropin- 
independent macronodular adrenal hyperplasia compared with other adrenocortical tumors. Journal of Clinical Endocrinology and Metabolism 94 2930-2937. (doi:10.1210/jc.2009-0516)

Huber AH, Nelson WJ \& Weis WI 1997 Three-dimensional structure of the armadillo repeat region of $\beta$-catenin. Cell 90 871-882. (doi:10.1016/ S0092-8674(00)80352-9)

Imohl M, Koditz R, Stachon A, Muller KM, Nicolas V, Pfeilschifter J \& Krieg M 2002 Catecholamine-dependent hereditary Cushing's syndrome - follow-up after unilateral adrenalectomy. Medizinische Klinik 97 747-753. (doi:10.1007/s00063-002-1220-2)

Iwata M, Oki Y, Okazawa T, Ishizawa S, Taka C, Yamazaki K, Tobe K, Fukuoka J, Sasano H \& Nishikawa T 2012 A rare case of adrenocorticotropic hormone (ACTH)-independent macroadrenal hyperplasia showing ectopic production of ACTH. Internal Medicine 51 2181-2187. (doi:10.2169/internalmedicine.51.7547)

Jang YH, Lim SB, Kim MJ, Chung HJ, Yoo HW, Byeon JS, Myung SJ, Lee W, Chun S \& Min WK 2010 Three novel mutations of the APC gene in Korean patients with familial adenomatous polyposis. Cancer Genetics and Cytogenetics 200 34-39. (doi:10.1016/j.cancergencyto.2010.03.015)

de Joussineau C, Sahut-Barnola I, Levy I, Saloustros E, Val P, Stratakis CA \& Martinez A 2012 The cAMP pathway and the control of adrenocortical development and growth. Molecular and Cellular Endocrinology 351 28-36. (doi:10.1016/j.mce.2011.10.006)

King A, Selak MA \& Gottlieb E 2006 Succinate dehydrogenase and fumarate hydratase: linking mitochondrial dysfunction and cancer. Oncogene $\mathbf{2 5}$ 4675-4682. (doi:10.1038/sj.onc.1209594)

Kirschner MA, Powell RD Jr \& Lipsett MB 1964 Cushing's syndrome: nodular cortical hyperplasia of adrenal glands with clinical and pathological features suggesting adrenocortical tumor. Journal of Clinical Endocrinology and Metabolism 24 947-955. (doi:10.1210/ jcem-24-10-947)

Lacroix A 2009 ACTH-independent macronodular adrenal hyperplasia. Best Practice \& Research. Clinical Endocrinology \& Metabolism 23 245-259. (doi:10.1016/j.beem.2008.10.011)

Lacroix A 2013 Heredity and cortisol regulation in bilateral macronodular adrenal hyperplasia. New England Journal of Medicine 369 2147-2149. (doi:10.1056/NEJMe1312792)

Lacroix A \& Bourdeau I 2005 Bilateral adrenal Cushing's syndrome: macronodular adrenal hyperplasia and primary pigmented nodular adrenocortical disease. Endocrinology and Metabolism Clinics of North America 34 441-458, x. (doi:10.1016/j.ecl.2005.01.004)

Lacroix A, Bolte E, Tremblay J, Dupre J, Poitras P, Fournier H, Garon J, Garrel D, Bayard F, Taillefer R et al. 1992 Gastric inhibitory polypeptidedependent cortisol hypersecretion - a new cause of Cushing's syndrome. New England Journal of Medicine 327 974-980. (doi:10.1056/NEJM199210013271402)

Lacroix A, Bolte E, Tremblay J \& Hamet P 1993 Gastrointestinal peptides and neoplasia ectopic gastric inhibitory polypeptide (GIP) receptors in adrenal glands causing food-dependent Cushing's syndrome. Trends in Endocrinology and Metabolism 4 307. (doi:10.1016/1043-2760(93) 90069-Q)

Lacroix A, Hamet P \& Boutin JM 1999 Leuprolide acetate therapy in luteinizing hormone-dependent Cushing's syndrome. New England Journal of Medicine 341 1577-1581. (doi:10.1056/NEJM199911183412104)

Lacroix A, Ndiaye N, Tremblay J \& Hamet P 2001 Ectopic and abnormal hormone receptors in adrenal Cushing's syndrome. Endocrine Reviews 22 75-110.

Lacroix A, Baldacchino V, Bourdeau I, Hamet P \& Tremblay J 2004 Cushing's syndrome variants secondary to aberrant hormone receptors. Trends in Endocrinology and Metabolism 15 375-382. (doi:10.1016/j.tem.2004.08.007)

Lacroix A, Bourdeau I, Lampron A, Mazzuco TL, Tremblay J \& Hamet P 2010 Aberrant G-protein coupled receptor expression in relation to adrenocortical overfunction. Clinical Endocrinology 73 1-15. (doi:10.1111/j.1365-2265.2009.03689.x)
Lampron A, Bourdeau I, Hamet P, Tremblay J \& Lacroix A 2006 Whole genome expression profiling of glucose-dependent insulinotropic peptide (GIP)- and adrenocorticotropin-dependent adrenal hyperplasias reveals novel targets for the study of GIP-dependent Cushing's syndrome. Journal of Clinical Endocrinology and Metabolism 91 3611-3618. (doi:10.1210/jc.2006-0221)

Lania AG, Mantovani G \& Spada A 2006 Mechanisms of disease: mutations of $\mathrm{G}$ proteins and G-protein-coupled receptors in endocrine diseases. Nature Clinical Practice. Endocrinology \& Metabolism 2 681-693. (doi:10.1038/ncpendmet0324)

Latronico AC, Reincke M, Mendonca BB, Arai K, Mora P, Allolio B, Wajchenberg BL, Chrousos GP \& Tsigos C 1995 No evidence for oncogenic mutations in the adrenocorticotropin receptor gene in human adrenocortical neoplasms. Journal of Clinical Endocrinology and Metabolism 80 875-877.

Lee S, Hwang R, Lee J, Rhee Y, Kim DJ, Chung UI \& Lim SK 2005 Ectopic expression of vasopressin $\mathrm{V} 1 \mathrm{~b}$ and $\mathrm{V} 2$ receptors in the adrenal glands of familial ACTH-independent macronodular adrenal hyperplasia. Clinical Endocrinology 63 625-630. (doi:10.1111/j.1365-2265.2005. 02387.x)

Lee KT, Arnott RD, McLean CA, Serpell JW \& Topliss DJ 2011 Corticotropinindependent macronodular adrenal hyperplasia associated with insulinoma. Endocrine Practice 17 e43-e47. (doi:10.4158/EP10213.CR)

Lefebvre H, Duparc C, Chartrel N, Jegou S, Pellerin A, Laquerriere A, Ivell R, Vaudry H \& Kuhn JM 2003 Intraadrenal adrenocorticotropin production in a case of bilateral macronodular adrenal hyperplasia causing Cushing's syndrome. Journal of Clinical Endocrinology and Metabolism $\mathbf{8 8}$ 3035-3042. (doi:10.1210/jc.2002-030014)

Lefebvre H, Prevost G \& Louiset E 2013 Autocrine/paracrine regulatory mechanisms in adrenocortical neoplasms responsible for primary adrenal hypercorticism. European Journal of Endocrinology 169 R115-R138. (doi:10.1530/EJE-13-0308)

Lehtonen HJ, Kiuru M, Ylisaukko-Oja SK, Salovaara R, Herva R, Koivisto PA, Vierimaa O, Aittomaki K, Pukkala E, Launonen V et al. 2006 Increased risk of cancer in patients with fumarate hydratase germline mutation. Journal of Medical Genetics 43 523-526. (doi:10.1136/jmg.2005.036400)

Libe R, Coste J, Guignat L, Tissier F, Lefebvre H, Barrande G, Ajzenberg C, Tauveron I, Clauser E, Dousset B et al. 2010 Aberrant cortisol regulations in bilateral macronodular adrenal hyperplasia: a frequent finding in a prospective study of 32 patients with overt or subclinical Cushing's syndrome. European Journal of Endocrinology 163 129-138. (doi:10.1530/EJE-10-0195)

Louiset E, Duparc C, Young J, Renouf S, Tetsi Nomigni M, Boutelet I, Libe R, Bram Z, Groussin L, Caron P et al. 2013 Intraadrenal corticotropin in bilateral macronodular adrenal hyperplasia. New England Journal of Medicine 369 2115-2125. (doi:10.1056/NEJMoa1215245)

Matyakhina L, Freedman RJ, Bourdeau I, Wei MH, Stergiopoulos SG, Chidakel A, Walther M, Abu-Asab M, Tsokos M, Keil M et al. 2005 Hereditary leiomyomatosis associated with bilateral, massive, macronodular adrenocortical disease and atypical Cushing syndrome: a clinical and molecular genetic investigation. Journal of Clinical Endocrinology and Metabolism 90 3773-3779. (doi:10.1210/jc.20042377)

Mazzuco TL, Chabre O, Feige JJ \& Thomas M 2006a Aberrant expression of human luteinizing hormone receptor by adrenocortical cells is sufficient to provoke both hyperplasia and Cushing's syndrome features. Journal of Clinical Endocrinology and Metabolism 91 196-203. (doi:10.1210/jc.2005-1975)

Mazzuco TL, Chabre O, Sturm N, Feige JJ \& Thomas M 2006b Ectopic expression of the gastric inhibitory polypeptide receptor gene is a sufficient genetic event to induce benign adrenocortical tumor in a xenotransplantation model. Endocrinology 147 782-790. (doi:10.1210/ en.2005-0921)

Mazzuco TL, Thomas M, Martinie M, Cherradi N, Sturm N, Feige JJ \& Chabre O 2007 Cellular and molecular abnormalities of a macronodular adrenal hyperplasia causing $\beta$-blocker-sensitive Cushing's 
syndrome. Arquivos Brasileiros de Endocrinologia e Metabologia 51 1452-1462. (doi:10.1590/S0004-27302007000900007)

Meoli E, Bossis I, Cazabat L, Mavrakis M, Horvath A, Stergiopoulos S, Shiferaw ML, Fumey G, Perlemoine K, Muchow M et al. 2008 Protein kinase A effects of an expressed PRKAR1A mutation associated with aggressive tumors. Cancer Research 68 3133-3141. (doi:10.1158/00085472.CAN-08-0064)

Minami S, Sugihara H, Sato J, Tatsukuchi A, Sugisaki Y, Sasano H \& Wakabayashi I 1996 ACTH independent Cushing's syndrome occurring in siblings. Clinical Endocrinology 44 483-488. (doi:10.1046/j.13652265.1996.682504.x)

Miyamura N, Taguchi T, Murata Y, Taketa K, Iwashita S, Matsumoto K, Nishikawa T, Toyonaga T, Sakakida M \& Araki E 2002 Inherited adrenocorticotropin-independent macronodular adrenal hyperplasia with abnormal cortisol secretion by vasopressin and catecholamines: detection of the aberrant hormone receptors on adrenal gland. Endocrine 19 319-326. (doi:10.1385/ENDO:19:3:319)

Newell-Price J, Bertagna X, Grossman AB \& Nieman LK 2006 Cushing's syndrome. Lancet 367 1605-1617. (doi:10.1016/S0140-6736(06) 68699-6)

Newey PJ \& Thakker RV 2011 Role of multiple endocrine neoplasia type 1 mutational analysis in clinical practice. Endocrine Practice 17(Suppl 3) 8-17. (doi:10.4158/EP10379.RA)

Nieman LK, Biller BM, Findling JW, Newell-Price J, Savage MO, Stewart PM \& Montori VM 2008 The diagnosis of Cushing's syndrome: an Endocrine Society Clinical Practice Guideline. Journal of Clinical Endocrinology and Metabolism 93 1526-1540. (doi:10.1210/jc.2008-0125)

Nies C, Bartsch DK, Ehlenz K, Wild A, Langer P, Fleischhacker S \& Rothmund M 2002 Familial ACTH-independent Cushing's syndrome with bilateral macronodular adrenal hyperplasia clinically affecting only female family members. Experimental and Clinical Endocrinology \& Diabetes 110 277-283. (doi:10.1055/s-2002-34590)

Pereira MAA, Araújo RS \& Bisi H 2001 Sindrome de Cushing Associada a Hiperplasia Macronodular das adrenais: Apresentação de um caso e revisão da literatura. Arquivos Brasileiros de Endocrinologia e Metabologia 45 619-627. (doi:10.1590/S0004-27302001000600015)

Pritchard CC, Cheng HH \& Tewari M 2012 MicroRNA profiling: approaches and considerations. Nature Reviews. Genetics 13 358-369. (doi:10.1038/ nrg3198)

Reznik Y, Allali-Zerah V, Chayvialle JA, Leroyer R, Leymarie P, Travert G, Lebrethon MC, Budi I, Balliere AM \& Mahoudeau J 1992 Fooddependent Cushing's syndrome mediated by aberrant adrenal sensitivity to gastric inhibitory polypeptide. New England Journal of Medicine 327 981-986. (doi:10.1056/NEJM199210013271403)

Ricarte Filho JC \& Kimura ET 2006 MicroRNAs: novel class of gene regulators involved in endocrine function and cancer. Arquivos Brasileiros de Endocrinologia e Metabologia 50 1102-1107. (doi:10.1590/ S0004-27302006000600018)

Sato M, Soma M, Nakayama T, Kosuge K, Suzuki R, Okada K, Komatsu K, Sugitani M \& Matsumoto K 2006 A case of adrenocorticotropinindependent bilateral adrenal macronodular hyperplasia (AIMAH) with primary hyperparathyroidism (PHPT). Endocrine Journal 53 111-117. (doi:10.1507/endocrj.53.111)

Schorr I \& Ney RL 1971 Abnormal hormone responses of an adrenocortical cancer adenyl cyclase. Journal of Clinical Investigation 50 1295-1300. (doi:10.1172/JCI106608)

Shuch B, Ricketts CJ, Vocke CD, Valera VA, Chen CC, Gautam R, Gupta GN, Gomez Macias GS, Merino MJ, Bratslavsky G et al. 2013 Adrenal nodular hyperplasia in hereditary leiomyomatosis and renal cell cancer. Journal of Urology 189 430-435. (doi:10.1016/j.juro.2012.07.139)
Skogseid B, Larsson C, Lindgren PG, Kvanta E, Rastad J, Theodorsson E, Wide L, Wilander E \& Oberg K 1992 Clinical and genetic features of adrenocortical lesions in multiple endocrine neoplasia type 1. Journal of Clinical Endocrinology and Metabolism 75 76-81.

Stratakis CA \& Boikos SA 2007 Genetics of adrenal tumors associated with Cushing's syndrome: a new classification for bilateral adrenocortical hyperplasias. Nature Clinical Practice. Endocrinology \& Metabolism 3 748-757. (doi:10.1038/ncpendmet0648)

Sudarshan S, Pinto PA, Neckers L \& Linehan WM 2007 Mechanisms of disease: hereditary leiomyomatosis and renal cell cancer - a distinct form of hereditary kidney cancer. Nature Clinical Practice. Urology 4 104-110. (doi:10.1038/ncpuro0711)

Swords FM, Baig A, Malchoff DM, Malchoff CD, Thorner MO, King PJ, Hunyady L \& Clark AJ 2002 Impaired desensitization of a mutant adrenocorticotropin receptor associated with apparent constitutive activity. Molecular Endocrinology 16 2746-2753. (doi:10.1210/me. 2002-0099)

Swords FM, Noon LA, King PJ \& Clark AJ 2004 Constitutive activation of the human ACTH receptor resulting from a synergistic interaction between two naturally occurring missense mutations in the MC2R gene. Molecular and Cellular Endocrinology 213 149-154. (doi:10.1016/ j.mce.2003.10.052)

Swords FM, Aylwin S, Perry L, Arola J, Grossman AB, Monson JP \& Clark AJ 2005 The aberrant expression of the gastric inhibitory polypeptide (GIP) receptor in adrenal hyperplasia: does chronic adrenocorticotropin exposure stimulate up-regulation of GIP receptors in Cushing's disease? Journal of Clinical Endocrinology and Metabolism 90 3009-3016. (doi:10.1210/jc.2004-0946)

Tewari R, Bailes E, Bunting KA \& Coates JC 2010 Armadillo-repeat protein functions: questions for little creatures. Trends in Cell Biology 20 470-481. (doi:10.1016/j.tcb.2010.05.003)

Thakker RV 2010 Multiple endocrine neoplasia type 1 (MEN1). Best Practice \& Research. Clinical Endocrinology \& Metabolism 24 355-370. (doi:10.1016/j.beem.2010.07.003)

Vernooij MW, Ikram MA, Tanghe HL, Vincent AJ, Hofman A, Krestin GP, Niessen WJ, Breteler MM \& van der Lugt A 2007 Incidental findings on brain MRI in the general population. New England Journal of Medicine 357 1821-1828. (doi:10.1056/NEJMoa070972)

Vezzosi D, Cartier D, Regnier C, Otal P, Bennet A, Parmentier F, Plantavid M, Lacroix A, Lefebvre H \& Caron P 2007 Familial adrenocorticotropinindependent macronodular adrenal hyperplasia with aberrant serotonin and vasopressin adrenal receptors. European Journal of Endocrinology 156 21-31. (doi:10.1530/eje.1.02324)

Watson TD, Patel SJ \& Nardi PM 2007 Case 121: familial adrenocorticotropin-independent macronodular adrenal hyperplasia causing Cushing syndrome. Radiology 244 923-926. (doi:10.1148/radiol. 2443041507)

Weinstein LS, Liu J, Sakamoto A, Xie T \& Chen M 2004 Minireview: GNAS: normal and abnormal functions. Endocrinology 145 5459-5464. (doi:10.1210/en.2004-0865)

Yamakita N, Murai T, Ito Y, Miura K, Ikeda T, Miyamoto K, Onami S \& Yoshida T 1997 Adrenocorticotropin-independent macronodular adrenocortical hyperplasia associated with multiple colon adenomas/ carcinomas which showed a point mutation in the APC gene. Internal Medicine 36 536-542. (doi:10.2169/internalmedicine.36.536)

Yoshida M, Hiroi M, Imai T, Kikumori T, Himeno T, Nakamura Y, Sasano H, Yamada M, Murakami Y, Nakamura S et al. 2011 A case of ACTHindependent macronodular adrenal hyperplasia associated with multiple endocrine neoplasia type 1. Endocrine Journal 58 269-277. (doi:10.1507/endocrj.K10E-218)

Received in final form 27 October 2014

Accepted 29 October 2014 http://joe.endocrinology-journals.org DOI: 10.1530/JOE-14-0568
(C) 2015 Society for Endocrinology Printed in Great Britain 